\title{
STEROID-INDUCED ANAPHYLAXIS
}

\author{
UMAMAHESWARI A*, BHUVANESWARI K, RAMALINGAM S
}

Department of Pharmacsology, PSG Institute of Medical Sciences and Research, Coimbatore, Tamil Nadu, India. Email: dr.uma.pharmac@gmail.com

Received: 04 April 2017, Revised and Accepted: 20 April 2017

\section{ABSTRACT}

To report a severe adverse drug reaction (ADR) due to administration of injection hydrocortisone sodium succinate and to explore the possibility of an association between injection hydrocortisone and the severe ADR. After getting ethics approval from the institution, ADR form and patient's clinical record from the Department of Cardiology, in a Private Medical College was received. In that, it was recorded as a 75-year-old male patient, a case of unstable angina with troponin $\mathrm{T}$ - positive, was posted for coronary angiogram developed a severe reaction to intravenous (IV) hydrocortisone 100 mg stat, given to prevent allergy to contrast dye used in the procedure. 5 minutes after drug administration, he developed sudden itching all over the body, hypotension blood pressure: $60 \mathrm{mmHg}$ and swelling of lips. No other drugs had been given at that time. The patient was already on aspirin $150 \mathrm{mg}$, clopidogrel $75 \mathrm{mg}$, and atorvastatin $80 \mathrm{mg}$, and enoxaparin $40 \mathrm{mg}$. The procedure was abandoned, and the patient was given injection pheniramine maleate $45.5 \mathrm{mg}$ IV, injection dopamine $10 \mathrm{mcg} / \mathrm{kg} / \mathrm{min}$ IV. He symptomatically improved within 6 hrs. Causality analysis using the WHO scale categorizes it as probable, as anaphylaxis occurred immediately after administration of hydrocortisone, no other drugs were given at that time, and rechallenge was not done. Very few cases of various steroid-induced anaphylaxis have been reported worldwide. This one among the rare ADR report may be due to the steroid or the excipients in the preparation. Skin prick test or in vitro (radioallergosorbent test assay) test can be done immediately to confirm the causative allergen in this case and would also help in identifying specific agents that will be tolerated in the future treatment.

Keywords: Allergic reaction, Excipients, Steroid.

(C) 2017 The Authors. Published by Innovare Academic Sciences Pvt Ltd. This is an open access article under the CC BY license (http://creativecommons. org/licenses/by/4. 0/) DOI: http://dx.doi.org/10.22159/ajpcr.2017.v10i8.18885

\section{INTRODUCTION}

The overall prevalence of Type I steroid hypersensitivity is estimated to be $0.3-0.5 \%$. The anti-allergic properties of steroids would seem to contradict their capacity to induce allergic reactions $[1,2]$. However, a few severe adverse reactions, including life-threatening ones caused by systemic steroids, have been reported over the past decades [3]. Here is one such rare case report.

\section{Aim and objective}

1. To report a severe adverse drug reaction (ADR) from injection hydrocortisone sodium succinate

2. To explore the possibility of an association between drug and the reaction.

After getting ethics approval from the institution, this report has been generated from the ADR reported using CDSCO ADR form:

- Day 1: A 75-year-old male patient, weight: $80 \mathrm{~kg}$, height: $176 \mathrm{~cm}$ came to Cardiology Department. On admission (day 1), $\mathrm{C} / \mathrm{O}$ left-sided chest pain $\mathrm{H} / \mathrm{O}$ hypertension, diabetes mellitus present, no $\mathrm{H} / \mathrm{O}$ cerebrovascular accident, transient ischemic attack, ischemic heart disease in the past, not a smoker, and electrocardiogram - AW non-ST elevation acute myocardial infarction, troponin $\mathrm{T}$ - positive, and hyperkalemia present. Then, he was diagnosed as unstable angina and started with low molecular weight heparin (LMWH) (enoxaparin) $40 \mathrm{mg} \mathrm{SC} \mathrm{BD,} \mathrm{tablet} \mathrm{pan}$ $40 \mathrm{mg}$, tablet ativan $1 \mathrm{mg}$.

- Day 2: Echocardiography showed adequate left ventricular function with no regional wall motion abnormalities. Then, the patient was on tablet aspirin $150 \mathrm{mg}$, tablet clopilet $75 \mathrm{mg}$, tablet atorlip $80 \mathrm{mg}$, LMWH, tablet pantoprazole, tablet ativan.

- Day 3: Patient was symptomatically better and planned for coronary angiogram on day 4.

- Day 4: Patient was advised to be on nil per oral from 7.30 am onwards. At $3.00 \mathrm{pm}$ injection hydrocortisone $100 \mathrm{mg}$ IV was given to prevent adverse reactions to the contrast dye, which will be used in the procedure. At $3.05 \mathrm{pm}$ patient developed angioedema, hypotension, and urticaria. His pulse rate was $52 / \mathrm{min}$, blood pressure: $60 \mathrm{mmHg}$, random blood glucose: $107 \mathrm{mg} / \mathrm{dl}$. No other drugs were given that time. The procedure was abandoned and treated with injection pheniramine maleate $1 \mathrm{amp}$ ( $45.5 \mathrm{mg}$ ) IV stat and injection dopamine $10 \mathrm{mcg} / \mathrm{min}$ initially followed by maintenance dose of $8 \mathrm{mcg} / \mathrm{ml} / \mathrm{h}$. - Day 5: Patient was in intensive care unit for 1 day under observation and improved symptomatically.

Causality analysis using the WHO scale categorizes the reaction as probable since the anaphylaxis occurred immediately after administration of hydrocortisone and no other drugs were given at that time. In addition, rechallenge was not done.

\section{DISCUSSION}

Steroid can cause allergic reactions which are of two types, the immediate, and delayed type of allergic reactions.

\section{Immediate type of allergic reaction}

This type of immediate allergic reaction is rare, seen with oral, intra-articular, or IV administration of glucocorticoids. It produces anaphylactic or anaphylactoid reactions $[4,5]$.

\section{Delayed type of allergic reaction}

These types of reactions are frequent, after topical application of glucocorticoids. It usually produces contact dermatitis $[6,7]$.

The reason behind these types of reactions could be due to cross reaction between different groups of steroids and it is most commonly seen with topical preparations. In case of the immediate type of allergic reactions, could be due to Type I hypersensitivity or an idiosyncratic reaction.

We also did a literature search in PubMed database search with mesh key words: "Hydrocortisone succinate AND anaphylaxis" and total no of articles were found to be 14 [Fig. 1]. 
Table 1: Published articles related to steroid-induced anaphylaxis

\begin{tabular}{|c|c|c|c|c|}
\hline Journal & Title & Drugs given & ADR & Skin prick test \\
\hline Der Anaesthesist 2002 & $\begin{array}{l}\text { Anaphylactic shock following } \\
\text { IV hydrocortisone succinate } \\
\text { administration }\end{array}$ & $\begin{array}{l}\text { A } 62 \text {-year-old asthmatic with } \\
\text { evidence of aspirin sensitivity. } \\
\text { Received } 100 \mathrm{mg} \text { hydrocortisone } \\
\text { hemisuccinate }\end{array}$ & $\begin{array}{l}\text { Developed severe } \\
\text { bronchospasm and } \\
\text { anaphylactic shock }\end{array}$ & $\begin{array}{l}\text { Positive for } \\
\text { hydrocortiisone } \\
\text { succinate }\end{array}$ \\
\hline $\begin{array}{l}\text { The British Journal of } \\
\text { Dermatology } 2004\end{array}$ & $\begin{array}{l}\text { Anaphylaxis to hydrocortisone } \\
\text { hemisuccinate with } \\
\text { cross-sensitivity to related } \\
\text { compounds in a pediatric patient }\end{array}$ & $\begin{array}{l}\text { A 9-year-old asthmatic child } \\
\text { received Hydrocortisone } \\
\text { hemisuccinate } 200 \mathrm{mg} \mathrm{IV}\end{array}$ & $\begin{array}{l}\text { Bronchospasm, facial } \\
\text { edema, urticarial rash } \\
\text { and hypotension }\end{array}$ & $\begin{array}{l}\text { Positive for } \\
\text { hydrocortisone } \\
\text { hemisuccinate }\end{array}$ \\
\hline $\begin{array}{l}\text { The British Journal of } \\
\text { Clinical Pharmacology } \\
2005\end{array}$ & $\begin{array}{l}\text { An unexpected response to IV } \\
\text { hydrocortisone succinate in an } \\
\text { asthmatic patient }\end{array}$ & $\begin{array}{l}\text { A 39-year-old asthmatic received } \\
200 \text { mg IV hydrocortisone } \\
\text { succinate }\end{array}$ & $\begin{array}{l}\text { Developed erythema, } \\
\text { tachycardia, and } \\
\text { orofacial edema }\end{array}$ & Not done \\
\hline $\begin{array}{l}\text { International Archives } \\
\text { of Allergy and } \\
\text { Immunology } 2011\end{array}$ & $\begin{array}{l}\text { Immediate-type hypersensitivity } \\
\text { to succinylated corticosteroids }\end{array}$ & $\begin{array}{l}\text { Methylprednisolone } \\
\text { hemisuccinate, prednisolone } \\
\text { sodium hemisuccinate }\end{array}$ & $\begin{array}{l}\text { Flushing, tachycardia, } \\
\text { and dyspnea }\end{array}$ & $\begin{array}{l}\text { Positive for } \\
\text { methylprednisolone } \\
\text { hemisuccinate, } \\
\text { prednisolone sodium } \\
\text { hemisuccinate }\end{array}$ \\
\hline
\end{tabular}

IV: Intravenous, ADR: Adverse drug reaction

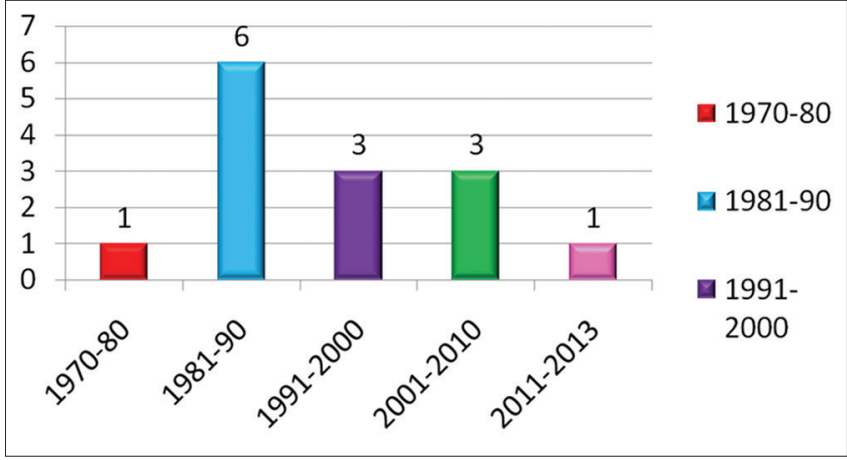

Fig. 1: Number of publications on steroid-induced anaphylaxis

Themostcommoncausativeagentistheexcipient(carboxymethylcellulose, succinate salt) $[4,5]$ rather than steroid molecule. This is evident from the studies revealing positive skin prick test with sodium succinate, but negative with hydrocortisone alone. The tests done are skin prick test - positive test suggests the immediate hypersensitivity $[8,9]$; radioallergosorbent assay - measure serum immunoglobulin E levels to the possible allergic agent; challenge test with steroids [8,9] (Table 1).

This patient was given injection enoxaparin (LMWH) from the day of admission till 1 day before the procedure. LMWH can also produce both immediate and delayed reactions [10]. Since there was a time interval of more than $12 \mathrm{hrs}$ after the last dose of LMWH and the reaction being typically an immediate hypersensitivity reaction and it was unlikely to be due to LMWH.

\section{CONCLUSION}

This case report illustrating an allergic reaction to hydrocortisone or the excipients in the preparation emphasizes that the clinicians should be aware that allergic reactions in response to systemic steroids are also possible. Worsening of symptoms may not always suggest treatment failure, but can also occur as a result of steroid administration which has the capacity to produce allergic reactions. However, a final administration of a challenge dose in a controlled setting remains the only way to identify safe steroids for these allergic patients.

\section{REFERENCES}

1. Appalasamy J, Sariff A. A survey of drug-related-problems among patients treated for allergy symptoms in community pharmacies at Negeri Sembilan, Malaysia. Int J Pharm Pharm Sci 2014;6(10):313-6.

2. Mirmoezzi M, Yazdi M, Gholami O. Comparative study on the efficacy of mometasone and fluticasone nasal sprays for treatment of allergic rhinitis. Int J Pharm Pharm Sci 2017;9(3):211-4.

3. Vatti R, Ali F, Chang C, Teuber S. Hypersensitivity reactions to corticosteroids. Clin Rev Allergy Immunol 2014;47(1):26-37.

4. Fulcher DA, Katelaris $\mathrm{CH}$. Anaphylactoid reaction to intravenous hydrocortisone sodium succinate: A case report and literature review. Med J 1991;154(3):210-4.

5. Burgdorff T, Venemalm L, Vogt T, Landthaler M, Stolz W. IgE-mediated anaphylactic reaction induced by succinate ester of methylprednisolone. Ann Allergy Asthma Immunol 2002;89(4):425-8.

6. Matura M, Goossens A. Contact allergy to corticosteroids. Allergy 2000;55(8):698-704.

7. Lutz ME, El-Azhary RA, Gibson LE, Fransway AF. Contact hypersensitivity to tixocortol pivalate. J Am Acad Dermatol 1998:38:691-5.

8. Dooms-Goossens A, Morren M. Results of routine patch testing with corticosteroid series in 2073 patients. Contact Dermat 1992;26(3):182-91.

9. Vind-Kezunovic D, Johansen JD, Carlsen BC. Prevalence of and factors influencing sensitization to corticosteroids in a Danish patch test population. Contact Dermat 2011;64(6):325-9.

10. Schindewolf M, Lindhoff-Last E, Ludwig RJ, Boehncke WH. Heparininduced lesions. Lancet 2012;380(9856):1867-79. 